\title{
PENDAMPINGAN KEGIATAN BELAJAR BAHASA INGGRIS BAGI SISWA DI MASA PANDEMIC
}

\author{
Oleh \\ Ulfan Mulyawan \\ Sekolah Tinggi Pariwisata Mataram \\ Email: ulfanmbojonis@ gmail.com
}

\begin{abstract}
Abstrak
Tidak mudahnya menguasai bahasa Inggris oleh para siswa karna keterbatasan penjelasan dan pendampingan langsung yang mumpuni selama kelas daring merupakan sebuah masalah yang perlu ditangani. Salah satu solusi dari hal tersebut adalah dengan memberikan pendampingan intensif dan reguler secara langsung (face to face) baik untuk menjelaskan materi secara utuh maupun penjelasan terkait maksud dari tugas yang mereka dapatkan. Kegiatan ini dilakukan oleh 3 tutor bahasa Inggris dalam kurun waktu 4 bulan. Kegiatan berlangsung dalam beberapa skema utama yakni; 1) Pembahasan maksud soal, 2) Penjelasan materi terkait tugas secara utuh, 3) Penerapan Game , 4) pemberian soal-soal latihan dan 5) pengerjaan tugas sekolah. Dari hasil pendampingan ini, kami mendapati adanya antusiasme yang sangat baik dari pihak orang tua terlebih para peserta yang merasa mendapatkan pemahaman lebih baik terkait materi. Namun beberapa kendala yang juga kami hadapi adalah terkait durasi waktu mengajar yang menjadi lebih panjang dari yang sebenarnya kami rencanakan.
\end{abstract}

\section{Keywords: Pendampingan \& Belajar Bahasa Inggris}

\section{PENDAHULUAN}

Penerapan bahasa Inggris sebagai salah satu poin yang harus dipelajari bahkan dikuasai, memang tidak lepas dari sistem pendidikan kita karna faktanya hampir di semua jenjang pendidikan mulai dari tingkatan yang sangat dasar yakni sekolah Dasar Hingga perguruan tinggi, pengenalan dan pengajaran tersebut tetap mendapat tempat tersendiri. Bahkan jika dibandingkan dengan bahasa Asing lain, Bahasa Inggris memiliki status yang berbeda dan mendapat tempat khusus karena menjadi mata pelajaran wajib yang harus di ajarkan di sekolah (Lauder, 2008).

Di dalam penerapan pengajarannya, khususnya di sekolah, Pembelajaran bahasa Inggris memang sedikit banyak menjadi salah satu momok bagi para siswa/I terutama karna bahasa Inggris menempati posisi sebagai bahasa asing dan kurang familiar di sebagian besar lingkungan siswa-siswi. Namun tentu saja, tingkat familiaritas bukanlah masalah tunggal yang sedang dihadapi karna proses pengajaran bahasa Inggris juga menjadi rumit karna hal lain seperti sarana dan prasarana.
Bahkan Jika dicermati lebih dalam maka unsur kecakapan seorang pendidik serta kemampuan intake / penyerapan peserta didik juga menjadi faktor signifikan di dalam menetukan keberhasilan pelaksanaannya. Dari segi tenaga pengajar misalnya, banyak dijumpai guru, terutama di daerah terpencil yang mengajarkan mata pelajaran di luar keahliannya (Munirah, 2015).

Kekhawatiran berlebih justru muncul dalam kondisi saat ini, dimana sebagian besar akses fisik menjadi terbatas termasuk kegiatan belajar yang sejauh ini harus dan masih dilaksanakan secara daring (Dalam jaringan) atau online. Kesulitan pemahaman oleh para siswa menjadi lebih kompleks yang dilandasi oleh keterbatasan akses mendapatkan bimbingan langsung untuk dapat memahami mata pelajaran serta tugas yang diberikan melalui kelas daring dari guru atau instruktur yang memiliki pemahaman yang baik. Jika dibiarkan berlarut-larut maka hal ini dapat beresiko menjadi hambatan dalam mengikuti kelas daring seperti berkurangnya minat serta motivasi peserta didik dalam mengikuti kelas 
daring. Bahkan, kelas daring yang berlangsung lama membuka peluang membuat siswa sulit berkonsentrasi mengikuti kelas (Handayani, 2020) yang tentu saja hal ini bisa berimbas pada perasaan jenuh. Kejenuhan yang di alami terusmenerus faktanya bisa memicu peserta didik untuk tidak serius mengikuti kegiatan belajar dan salah satunya bisa membuat peserta didik mengerjakan tugas secara asal-asalan (Anugrahana, 2020).

Fakta dilapangan yang kami temukan mengungkapkan bahwa permasalahan terkait dengan sulitnya memahami materi dan tugas yang diberikan masih banyak dijumpai seperti halnya di lingkungan Pejarakan, Ampenan dimana siswa-siswa sering ditemukan kesulitan memahami tugas yang diberikan oleh para guru melalui kelas daring sehingga, sangatlah tepat sekiranya untuk kami terjun langsung melakukan pendampingan untuk menguraikan atau mengatasi masalah yang didapatkan para siswa dengan jalan memberikan pemahaman maksud soal serta menjelaskan materi yang dijadikan tugas itu sendiri sehingga siswa-siswi diharapkan dapat mengerjakan tugas yang diberikan guru dengan baik dengan tingkat ketergantungan minimal untuk tugas yang sama di kemudian hari.

\section{LANDASAN TEORI \\ Pendampingan}

Menurut Purwasasmita (2008), Pendampingan adalah tindakan menemani oleh seseorang dalam berbagai hal yang jika dikaitkan kearah pembelajaran dalam kelompok masyarakat dapat diartikan sebagai usaha untuk membuat sekelompok orang yang memiliki kebutuhan dan potensi yang homogen untuk belajar berdasarkan interaksi seluruh anggota.

Dalam kegiatan pendampingan itu sendiri, seorang pendamping haruslah sadar bahwa salah satu peran yang harus dimiliki adalah sebagai seorang fasilitator dimana makna fasilitator dalam pengelolaan kegiatan belajar dimasyarakat adalah; (1) sebagai narasumber; (2) sebagai guru; (3) sebagai mediator dan (4) sebagai penantang (Yunus, 1999: 6) dalam Purwasasmita, 2010). Hal ini secara eksplisit dapat dimaknai sebagai usaha seorang pendamping dalam kegiatan pembelajaran di dalam kelompok masyarakat harus memenuhi unsur lengkap sebagai penyedia, penghantar, penghubung dan stimulant bagi sebuah kelompok belajar.

\section{Belajar dan Mengajar.}

Banyaknya teori yang melandasi rumusan belajar melahirkan definisi dan pemahaman yang beragam pula terkait tindakan belajar itu sendiri. Belajar, menurut Sequeira (2012) adalah proses untuk mengalami perubahan yang di dalamnya membawa perubahan sikap, pengetahuan serta keterampilan. Schunk (2012) dari sudut pandang pendidikan mendefinisikan belajar sebagai perubahan sikap yang bertahan lama dan diperoleh dari pengalaman. Berdasarkan definisi ini, secara umum Schunk (2012) memberikan 3 kriteria utama dalam belajar yakni pertama, adanya perubahan, dimana seseorang dikatakan belajar ketika mampu melakukan sesuatu dengann cara yang berbeda. Kedua, bertahan lama, yang artinya adalah sikap atau kemampuan yang didaptkan dan telah merubah sikap serta kemampuan sebelumnya tidak mudah berubah atau hilang dan cenderung akan mengendap di dalam diri seseorang. Ia juga mengilustrasikan bahwa perubahan ini tidak mudah menghilang seperti reaksi alkohol dalam tubuh manusia. Ia kemudian menegaskan bahwa jika ada perubahan di dalam diri seseorang dan bertahan sementara, maka itu bukanlah tindakan belajar dan ketiga, tindakan belajar itu muncul melalui pengalaman, baik itu praktik, pengamatan, latihan dan lain-lain.

Sejalan dengan hal tersebut Nurjan (2015:17) mengatakan bahwa dari segi psikologi, belajar adalah "tahapan perubahan seluruh tingkah laku individu yang relative menetap sebagai hasil pengalaman dan interaksi dengan lingkungan yang melibatkan proses kognitif' dimana jika ditinjau dari ciri umum unsur pendidikan, belajar dan perkembangan, maka tindakan dan hasil belajar dapat dilihat dari 3 hal utama yakni bertambahnya pengetahuan, perilaku (kognitif, afektif \& psikomotor) dan kepribadian. Itu berarti bahwa bentuk ideal dari hasil belajar 
dapat dilihat dari perubahan yang dialami oleh pembelajar tersebut dan bersifat tahan lama.

Jika melaksanakan kegiatan belajar adalah dorongan internal dari dalam peserta belajar, maka mengajar adalah proses external (Sequeira, 2012) yang diperlukan guna memaksimalkan proses belajar. Dalam hal ini tentu saja unsur kecakapan pengajar dan peserta belajar memiliki peran penting untuk saling mendukung karena efektifitas kegiatan belajar dan mengajar tergantung dari kemampuan mengajar Guru dan belajar pembelajar (Dharmaraj, 2015). Itu berarti bahwa, setidaknya dibutuhkan peran seorang guru/tutor/instruktur yang melakukan kegiatan mengajar untuk pencapaian maksimal dan efektif dari sebuah kegiatan belajar.

Aktifitas mengajar dapat didefinisikan sebagai kegiatan atau proses yang ilmiah dimana unsur utamanya terdiri dari materi, komunikasi dan respond (umpan balik) (Rajagopalan, 2019:6). Di sisi lain, mengajar juga dapat diartikan sebagai proses memfasilitasi kegiatan belajar yang didalamnya terdapat misi untuk mencapai tujuan pendidikan dan tentunya seorang pengajar harus memiliki pengetahuan dan kemampuan yang baik (Dharmaraj, 2015).

Dalam process mengajar, menurut Davis \& Glaser (1962) dalam Rajagopalan (2019) ada 4 struktur umum yang setidaknya perlu dilakukan yakni:

1. Merencanakan kegiatan mengajar termasuk melakukan analisa konten / isi materi, identifikasi serta menuliskan tujuan darei pembelajaran.

2. Melakukan penataan pengajaran yang mengindikasikan pada strategi mengajar tertentu guna mencapai tujuan mengajar.

3. Mengidentifikasi / menentukan strategi belajar mengajar yang sesuai untuk penyampaian materi yang efektif.

4. Mengatur kegiatan belajar mengajar, dimana penilain tujuan pembelajaran terfokus pada performa atau kecakapan siswa dan hal ini menjadi feedback bagi guru dan murid.

Menjadi sangat penting kemudian bagi seorang pengajar untuk memperhatikan aspek- aspek dasar tersebut di atas sebelum melakukan kegiatan mengajar.

Metode (Game) Dalam Pengajaran Bahasa Inggris

Pemilihan metode belajar yang tepat merupakan salah satu unsur penentu untuk mencapai tujuan pembelajaran (Mardiah, 2015). Salah satu metode dalam pembelajaran yang hingga saat ini berkembang adalah penggunaan game yang dalam banyak penelitian menunjukkan hasil positif dalam meningkatkan motifasi maupun hasil belajar siswa. Beberapa diantaranya yakni Rabba \& Tanni (2014) dalam penelitiannya tentang penggunaan game dalam menumbuhkan motifasi siswa dalam pembelajaran bahasa Inggris menemukan adanya efektifitas positif permainan diantaranya dapat menumbuhkan perasaan senang, motifasi dan semangat. AlShawi (2014) juga menemukan bahwa selain meningkatkan antusiasme, penggunaan permainan dalam proses belajar juga memberikan peningkatan signifikan terhadap kemampuan peserta belajar untuk mengingat kosa-kata baru dalam bahasa Inggris.

Mengacu pada tren positif yan ditunjukkan beberapa penelitian di atas terkait hasil baik yang dihasilkan dengan penggunaan game di dalam kegiatan pembelajaran Bahasa Inggris, tentu bukan merupakan hal buruk jika kemudian penggunaan metode game diaplikasikan di dalam kegiatan pengabdian ini. Belajar di Tengah Pandemic

\section{A. Belajar online / Virtual learning}

Sejatinya, belajar online atau Virtual learning oleh Munawaroh (2005) dikatakan muncul akibat dampak dari perkembangan teknologi informasi yang begitu pesat dimana virtual learning itu sendiri didefinisikan sebagai proses atau kegiatan belajar dalam kelas virtual dengan fasilitas utama media komputer dan jaringan. Senada dengan hal tersebut, Yunus (2019) mengatakan bahwa pembelajaran online merupakan proses belajar yang menggunakan jaringan internet untuk terhubung antara satu dengan yang lain dengan bantuan perangkat elektronik baik HP maupun Laptop. Dalam prosesnya, guru dan murid tidaklah bertemu fisik secara langsung dan hanya mengikuti 
kegiatan belajar dari lokasi masing-masing. Jadi, pembelajaran online atau e-learning merupakan proses pembelajaran jarak jauh dimana selama kegiatan berlangsung membutuhkan jaringan Internet (Setiawardhani, 2003).

Keterbatasan akses melakukan kontak yang terjadi antara perorangan maupun kelompok terhitung sejak mewabahnya COVID-19 di awal tahun 2019 di Wuhan, China kemudian menjadi salah satu titik awal dari pelaksanaan kegiatan berbasis online secara besar-besaran yang hingga saat ini masih terus berkembang. Di dalam dunia pendidikan misalnya, dampak penyebaran COVID-19 telah merubah system pembelajaran secara global hampir dilakukan oleh seluruh Negara di dunia yakni merubah pembelajaran system konvensional (tatap muka) menjadi pembelajaran berbasis online (Soni, 2020).

Di Indonesia sendiri, kegiatan belajar mengajar secara online secara langsung di instruksikan oleh menteri pendidikan untuk diterapkan oleh seluruh jenjang pendidikan melalui Surat Edaran no 4 Tahun 2020 yang berarti bahwa seluruh peserta didik dan tenaga pendidik/pengajar diinstruksikan untuk tetap melaksanakan proses belajar mengajar dengan tetap berada di rumah atau biasa di sebut belajar dari rumah.

\section{B. Panduan Pembelajaran Tatap Muka di Era New Normal}

Dalam perkembangannya, seiring dengan meningkatnya kesadaran masyarakat dunia tentang protocol kesehatan. Keterbatasan jarak yang sebelumnya sangat ketat kini mulai dilonggarkan. Sistem belajar-mengajar perlahan mulai berubah yakni dari sebelumnya menerapkan penuh kelas daring menjadi berangsur-angsur menjadi kelas tatap muka. Proses belajarpun kemudian berkembang menjadi 2 system yang terintegrasi yakni sytem offline (luring) dan online (daring) atau dikenal sebagai Blended Learning (BL).

Pengenalan tatanan kehidupan baru atau New normal pada dunia pendidikan tentu menghasilkan adaptasi baru yang luar biasa terlebih bagi system pembelajaran face to face atau tatap muka. Berdasarkan keputusan bersama Menteri Pendidikan dan Kebudayaan, Menteri Agama, Menteri Kesehatan, dan Menteri Dalam Negeri yang tertuang dalam Panduan Penyelenggaraan pembelajaran Pada tahun ajaran 2020/2021 dan Tahun akademik 2020/2021 Di masa pandemic Coronavirus disease 2019 (covid-19), bahwa seluruh unsur warga satuan pendidikan haruslah mengikuti beberapa kegiatan selama kegiatan belajar serta setelah kegiatan belajar berakhir sebagai berikut:

\section{a. Selama Kegiatan Belajar Mengajar berlangsung:}

1. Menggunakan masker dan menerapkan jaga jarak minimal 1,5 (satu koma lima) meter;

2. Menggunakan alat belajar, alat musik, dan alat makan minum pribadi; dilarang pinjam-meminjam peralatan;

3. Memberikan pengumuman di seluruh area satuan pendidikan secara berulang dan intensif terkait Penggunaaan masker, CTPS, dan jaga jarak;

4. Melakukan pengamatan visual kesehatan warga satuan pendidikan,

5. jika ada yang memiliki gejala gangguan kesehatan maka harus ikuti protocol kesehatan satuan pendidikan

\section{b. Selesai Kegiatan Belajar Mengajar:}

1. Tetap menggunakan masker dan melakukan CTPS Sebelum meninggalkan ruang kelas;

2. Keluar ruangan kelas dan satuan pendidikan dengan berbaris sambil menerapkan jaga jarak;

3. Penjemput peserta didik menunggu di lokasi yang sudah disediakan dan melakukan jaga jarak sesuai dengan tempat duduk dan/atau jarak antri yang sudah ditandai.

\section{METODE PELAKSANAAN}

Metode Kegiatan pendampingan dan Peserta

Proses pendampingan ini akan diaplikasikan dalam bentuk pengajaran yang terbagi kedalam beberapa metode yakni Ceramah, Game dan Latihan soal sehingga di 
dalam setiap prosesnya terdapat latihan untuk membuat para siswa terbiasa dengan soal yang mereka dapatkan. Adapun urutan kegiatannya adalah 1) analisa tugas, 2) penjelasan materi 3)penugasan dan 4) Pembahasan / mengerjakan tugas. Pendampingan akan diberikan untuk siswa/I yang berdomisili di desa Pejarakan, Kec. Ampenan yang mencakup level SD, SMP hingga SMA yang tersebar di sekolah-sekolah diseputaran Mataram dan Lombok Barat berjumlah 26 siswa-siswi. Namun jumlah ini akan bisa berkurang dan bertambah sembari berjalannyanya kegiatan.

\section{Materi Belajar}

Sebelum menentukan materi, terlebih dahulu kami mempelajari kurikulum bahasa Inggris masing-masing pada tingkatan SD, SMP dan SMA serta sedikit melakukan adaptasi dari CEFR. Berangkat dari hasil analisa tersebut, Materi yang kemudian akan kami gunakan adalah gabungan dari materimateri umum tingkat SD, SMP dan SMA yang terdapat di dalam modul-modul sekolah sesuai jenjangnya masing-masing tersebut serta materi tambahan yang sudah kami persiapkan sebelumnya. Guna memancing dan menambah motivasi belajar siswa, kami juga mengumpulkan beberapa sumber game pembelajaran yang akan kami sesuaikan dengan materi yang akan diajarkan.

\section{Tempat}

Proses pendampingan (kegiatan belajar) akan dilaksanakan di salah satu rumah warga yang bersedia dijadikan lokasi proses pembelajaran di area Pejarakan. Lokasi ini kami dapatkan berdasarkan bentuk apresiasi dari salah satu warga yang merupakan keluarga dari salah satu tutor dalam kegiatan pendampingan ini. Lokasi rumah warga ini memiliki salah satu bagian yang cukup untuk menampung 10-15 peserta ditambah dengan halaman yang cukup memadai untuk mendukung kegiatan game pembelajaran yang akan kami terapkan.

\section{Waktu}

Kegiatan pendampingan ini akan berlangsung dengan durasi selama 4 bulan terhitung sejak Agustus 2019 - hingga akhir tahun sembari menunggu perkembangan terbaru terkait system pembelajaran yang akan diterapkan nantinya. Terkait dengan jadwal pelaksanaan, pendampingan dilakukan 3 kali dalam satu minggu yakni Senin, Rabu dan Sabtu dan dibagi kedalam 3 sesi waktu yang berbeda yakni pada pukul 15.00-16.30, $17.00-$ 18.30 dan $19.00-20.30$.

\section{HASIL DAN PEMBAHASAN}

\section{Penyampaian Dan Analisa Tugas}

Proses ini merupakan bagian awal dimana siswa/I diminta untuk menyampaikan tugas yang mereka dapatkan dari sekolah masingmasing yang sudah disalin dalam bentuk kertas. Namun terlebih dahulu kami malakukan grouping atau pengelompokkan bagi mereka yang berasal dari sekolah atau bahkan kelas yang sama. Kalaupun kemudian mereka berasal dari satu sekolah namun tugasnya berbeda, maka kami meminta secara acak salah satu siswa untuk membacakan tugasnya dan menanyakan siapa saja yang memiliki tugas yang mirip atau bahkan sama, jadi tidak perlu membacakannya juga. Tujuan meminta siswa/I membaca ini adalah sebagai tindakan pembiasaan terhadap mereka agar tetap aktif dan berpartisipasi dalam kegiatan. Selama tahap ini berlangsung, tutor akan mencatat poin tugas untuk dikaitkan dengan materi yang akan diajarkan / dijelaskan. Setelah mendapatkan materi yang paling dominan (materi paling banyak menjadi tugas) maka materi tersebutlah yang akan dijelaskan pada tahap berikutnya. Untuk materi yang tidak banyak muncul sebagai tugas, akan langsung dijelaskan kepada siswa terkait beserta pemecahan masalah atas tugas yang didapatkannya namun bersamaan dengan pengerjaan tugas oleh siswa/I lainnya dikegiatan akhir pertemuan. Pada tahap awal ini biasanya tutor memberikan pertanyaanpertanyaan pancingan terkait tugas yang mereka bacakan untuk mendalami pemahaman siswa. Ternyata, memang tingkat pemahaman siswa tidak terlalu baik walaupun ada beberapa diantara mereka yang tau gambaran singkatnya seperti memberikan pertanyaan untuk meyakinkan kebenaran pemahamannya. Jadi, setelahnya, kami selalu meminta agar seluruh 
siswa memperhatiakan dengan baik penjelasan materi tersebut terlebih dahulu.

Gambar 1. Dokumentasi peserta ketika menyampaikan tugas.
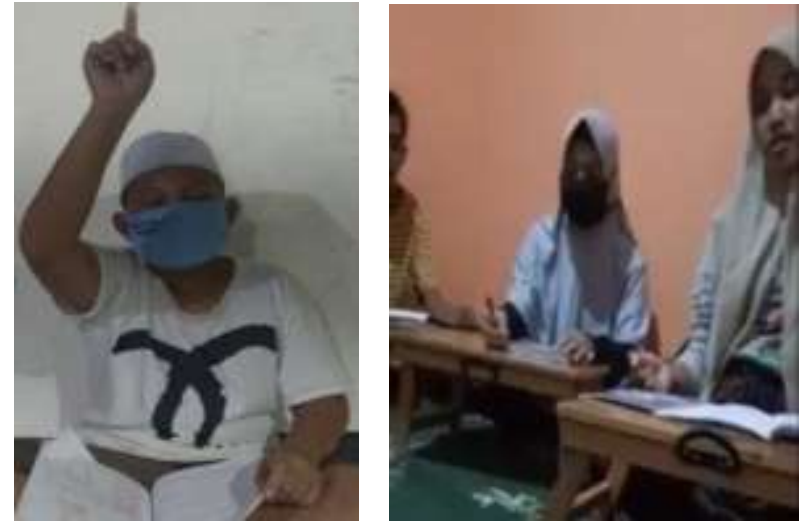

2. Ceramah

Sebagai proses lanjutan setelah siswa/I membacakan tugasnya masing-masing yang didapatkan dari kelas online, maka tutor akan memberikan penjelasan terkait dengan materi yang paling dominan muncul sebagai tugas. Penjelasan materi diberikan dengan cara yang paling mudah untuk dipahami misalnya dengan menyelipkan bahasa daerah untuk mengartikan kosakata yang sulit ditemui bahkan dalam bahasa Indonesia. Walaupun materi tersebut telah diberikan selama daring, kami tetap memberikan penjelasan ulang secara utuh dan detail guna membuat siswa menjadi paham atau bahkan lebih paham. Karna berdasarkan masalah yang kami temukan sebelumnya, selain mengerjakan tugas, sebagian besar siswa/I juga terkendala dengan pemahaman terkait materi itu sendiri. Selama kegiatan ini berlangsung, kami tetap memberikan kesempatan bagi peserta yang ingin bertanya terlebih jika mereka merasa bingung dengan materi yang disampaikan baik saat penjelasan materi maupun diakhir penjelasan. Pada proses ini, para peserta memang terlihat banyak bertanya terlebih jika terkait dengan materi tenses (Grammar). Selain itu, beberapa pertanyaan yang muncul lebih karena rasa keingintahuannya menghubungkan pelajaran dengan hal-hal yang mereka temukan. Untuk itu kami tidak membatasi jumlah peserta yang ingin bertanya. Hanya saja, untuk mengurangi konsumtif waktu berlebihan di tahap ini, kami berikan kesempatan 1 orang hanya boleh bertanya maksimal 2 kali. Selain waktu, tidak ada kendala signifikan selama fase ini berlangsung.

\section{Gambar 2. Dokumentasi saat pengajar menyampaikan materi}

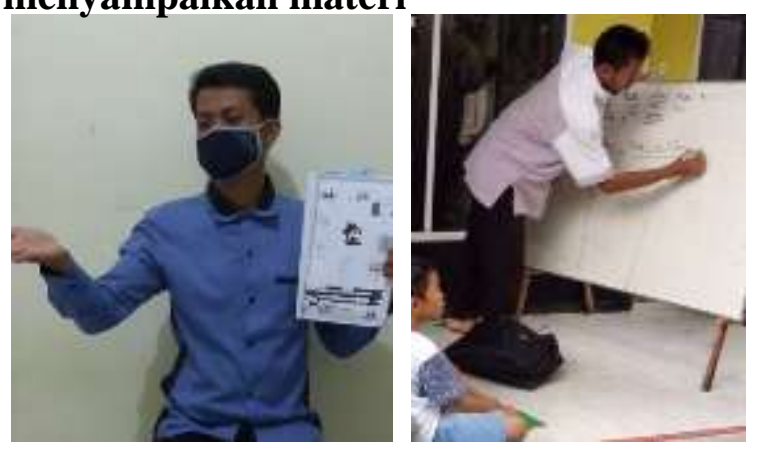

\section{Pelaksanaan Game}

Setelah materi dijelaskan, kami selalu memperkuat penjelasan tersebut dengan Game atau permainan pembelajaran. Namun, penting terlebih dahulu penulis menentukan batasan bahwa game / permainan yang kami maksud dalam kegiatan ini adalah penggunaan game sederhana yang tidak berbasis komputer. Jadi, permainan yang diaplikasikan adalah permainan sederhana yang mudah untuk dimainkan dengan fasilitas seadanya seperti Flash card, papan tulis, kertas dll. Setiap permainan kami setting sesuai dengan focus dari materi yang kami sampaikan sebelumnya. Biasanya kegiatan game berlangsung di halaman depan rumah warga tempat belajar terlebih saat melakukan kegiatan game yang membutuhkan lahan yang luas. Pada tahap permainan ini, terlihat jelas antusias dan semangat siswa untuk ikut berpartisipasi karena permainan ini di atur supaya mengandung unsur kompetisi di dalamnya, baik perorangan maupun perkelompok. Kendala yang muncul dalam tahap ini adalah karna kegiatannya relatif konsumtif waktu.

Gambar 3. Dokumentasi peserta ketika mengikuti permainan
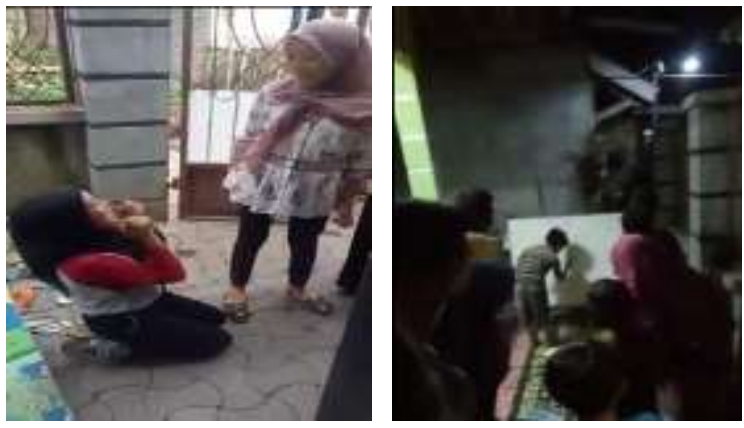


\section{Latihan}

Pada tahap ini, biasanya kami memberikan soal-soal latihan kecil yang mengarah ke tugas siswa/i. Beberapa bentuk soal sudah terlebih dahulu kami siapkan. Namun, beberapa soal latihan terkadang harus kami modifikasi menyesuaikan kebutuhan materi yang sedang disampaikan dan harus dituliskan di papan. Pada tahap ini biasanya menjadi tahap dimana siswa banyak menanyakan instruksi tugas untuk meyakinkan apakah pemahaman mereka sama dengan maksud tugas. Untuk tidak terlalu banyak menghabiskan waktu biasanya kami memberikan jumlah latihan yang sangat terbatas yakni maksimal 5 latihan sederhana.

Gambar 4. Dokumentasi saat mengerjakan soal latihan
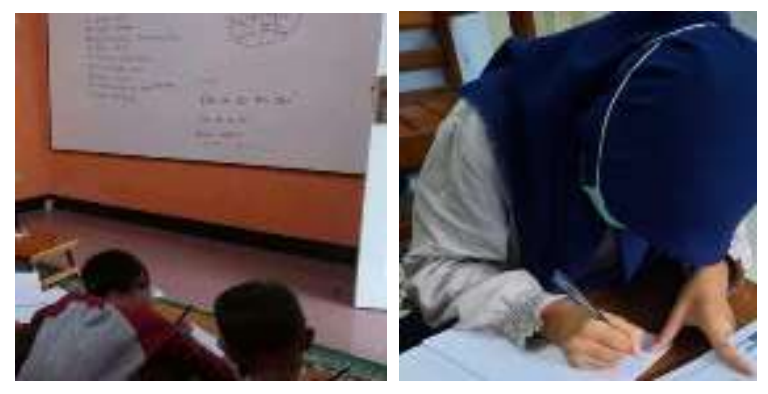

\section{Pembahasan}

Di sesi ini, kami menanyakan kembali terkait pemahaman instruksi tugas para peserta. Jika masih ada yang belum paham maka akan kami ulangi menjelaskan maksudnya dan jika mereka paham maka tutor langsung menginstruksikan peserta untuk mengerjakannya. Pada prosesnya, kami selalu inisiatif menanyakan kesulitan lain yang dihadapi siswa dan selalu memberikan solusi yang mengarahkan siswa/I tersebut untuk mendapatkan arah jawabannya dengan memaksimalkan untuk tidak membantu menjawab. Namun, tentu saja sebelum kegiatan berakhir, tutor selalu memastikan bahwa semua tugas siswa sudah terselesaikan. Untuk siswa/I yang daya tangkapnya rendah memang terkadang masih saja memberikan beberpa pertanyaan. Namun, secara umum, tidak ada kendala berarti pada tahap ini. Sebelum kegiatan kami tutup dan siswa selesai mengerjakan tugas, kami biasanya menanyakan pemahaman mereka dan sebagian besar diantara mereka merasa senang karena akhirnya menjadi lebih paham dan bisa menyelesaikan tugasnya. Antusiasme juga ditunjukkan oleh mereka ketika memberikan respon terkait dengan belajar dengan cara melakukan permainan.

Gambar 5. Dokumentasi saat mengerjakan tugas

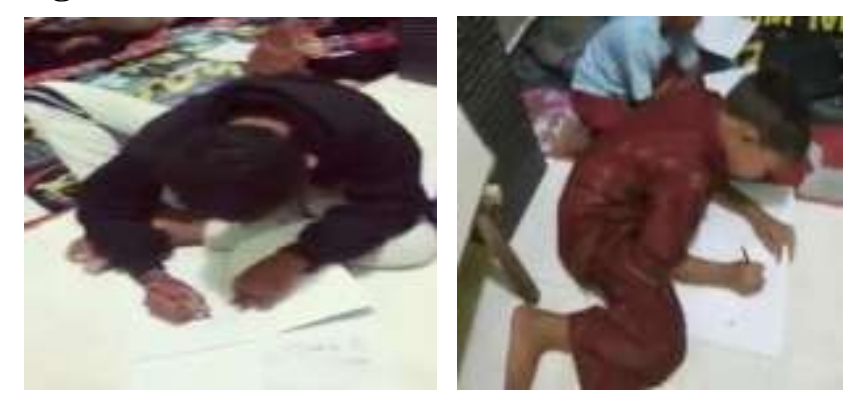

\section{PENUTUP}

\section{Kesimpulan}

Pemahaman rata-rata siswa ketika datang membawa tugas memang tidak terlalu baik bahkan jika ditanyakan terkait materi terkait dengan tugas, mereka tidak mampu menjelaskan dengan baik. Namun tentu saja hal ini tidak bisa menggeneralisasi kondisi semua siswa karena beberapa diantaranya sudah memiliki pemahaman yang cukup baik. Penerapan permainan dalam memperkuat pemahaman materi yang dijelaskan ternyata cukup memberikan dampak positif yang dibuktikan dengan kemampuan para peserta dalam mengikuti dan menyelesaikan instruksi permainan secara keseluruhan walaupun tidak sempurna. Selain itu, permainan yang kami adakan juga berpengaruh baik terhadap antusiasme yang dibuktikan dengan keikutsertaan siswa dalam permainan dengan semangat dan selalu memiliki rasa ingin menang. Dari hasil pengamatan terhadap proses akhir yakni mengerjakan tugas, terlihat para peserta lebih memiliki kepercayaan diri ketika mengerjakannya walaupun tentu saja tidak lepas dari kebingungan mereka yang terkadang disampaikan lewat beberapa pertanyaan pengulangan maksud tugas. Namun hal tersebut tidak signifikan. Hal yang patut disyukuri adalah bahwa mereka merasa senang karena bisa paham dan menyelesaikan tugas terlebih 
karena mereka bisa bertanya langsung kepada para tutor terkait hal-hal yang tidak mereka pahami.

\section{DAFTAR PUSTAKA}

[1] Al-Shawi, M.A (2014). Using Game Strategy for Motivating Students to Learn New English Vocabulary. AMARABAC, Journal of American Arabic Academy for Sciences and Technology. Volume 5, Number 12, (2014), PP. 137-146

[2] Anugrahana, Andi (2020). Hambatan, Solusi dan Harapan: Pembelajaran Daring Selama Masa Pandemi Covid-19 Oleh Guru Sekolah Dasar. Scholaria: Jurnal Pendidikan dan Kebudayaan, Vol. 10 No. 3, September 2020: 282-289.

[3] Dharmaraj (2015). Centre for distance education; learning and teaching. Diakses pada 25 September 2020 dari http://www.bdu.ac.in/cde/docs/ebooks/BE d/I/LEARNING\%20AND\%20TEACHIN G.pdf

[4] Handayani, Lina (2020). Keuntungan, Kendala dan Solusi Pembelajaran Online Selama Pandemi Covid-19 : Studi Ekploratif di SMPN 3 Bae Kudus. Journal Industrial Engineering \& Management Research ( Jiemar). Vol. 1 No. 2 : JULI 2020.

[5] Lauder, A. (2008). The Status And Function Of English In Indonesia: A Review Of Key Factors. Makara, sosial humaniora, vol. 12, no. 1, juli 2008: 9-20.

[6] Mardiah (2015). Metode Permainan Dalam Pembelajaran Bahasa Indonesia Di Madrasah Ibtidaiyah. Jurnal Mitra PGM, Volume 1 No. 1.

[7] Munawaroh, Istiani (2005). Virtual Learning dalam pembelajaran jarak jauh. Majalah Ilmiah pembelajaran nomor 2, Vol.1, Oktober 2005.

[8] Munirah (2015). Sistem Pendidikan Di Indonesia: antara keinginan dan realita. Diakses pada 25 September 2019 dari http://journal.uinalauddin.ac.id/index.php/ auladuna/article/view/879.
[9] Nurjan, Syarifan (2015:17). Psikologi Belajar. Penerbit Wade Group, Ponorogo, Indonesia.

[10]Panduan Penyelenggaraan Pembelajaran Pada Tahun Ajaran 2020/2021 Dan Tahun Akademik 2020/2021 Di Masa Pandemi Coronavirus Disease 2019 (Covid-19). (Keputusan Bersama 4 Menteri; Menteri Pendidikan dan Kebudayaan, Menteri Agama, Menteri Kesehatan, dan Menteri Dalam Negeri). Diakses Pada 25 September dari https://bersamahadapikorona.kemdikbud.g o.id/wpcontent/uploads/2020/08/SALINA N_REVISI-SKB-4-MENTERIPTM_AGUSTUS-2020.pdf.

[11]Purwasasmita, M (2010) Strategi Pendampingan Dalam Peningkatan Kemandirian Belajar Masyarakat. ejournal.upi.edu. Diakses pada Oktober $2020 \quad$ dari https://media.neliti.com/media/publication s/73058-ID-strategi-pendampingan-daumpeningkatan-k.pdf.

[12] Rabba, A.A.A.M \& Tanni, Z.A.I (2014). Using games to promote students' motivation towards Learning English. AlQuds Open University Journal for Educational \& Psychological Research \& Studies - Vol. 2 - No. 5 - April 2014.

[13] Rajagopalan, Isola (2019). "Concept of Teaching." Shanlax International Journal of Education, vol. 7, no. 2, 2019, 5-8. https://doi.org/10.34293/

education.v7i2.329

[14] Schunk, Dale. H (2012). Learning Theories An Educational Perspective. Published by Pearson Education, Inc.

[15] Sequeira, A.H (2012). Introduction To Concepts Of Teaching And Learning. National Institute of Technology Karnataka, Surathkal, India.

[16] Setiawardhani, S.T (2003). Pembelajaran Elektronik (E-Learning) Dan Internet Dalam Rangka Mengoptimalkan Kreativitas Belajar Siswa. Edunomic, Jurnal Ilmiah Pend. Ekonomi, Volume 1 Nomor 2, September 2013, Hal. 82-96. 
[17] Soni, V.D (2020). Global Impact of ELearning during Covid-19. SSRN Electronic Journal.

[18] Tria, J. Z. (2020). The COVID-19 Pandemic through the Lens of Education in the Philippines: The New Normal. International Journal of Pedagogical Development and Lifelong Learning, 1(1), ep2001. https://doi.org/10.30935/ijpdl1/8311

[19] Wan, Ya Shin. (2020). Education during COVID-19. Diakses pada 12 September dari https://www.researchgate.net/publication/ 340860261

[20] Yunus, Muhammad (2019). Pembelajaran Online. Universitas Terbuka. Diakses pada 20 September https://docplayer.info/137577286Pembelaj aran-online-mohamad-yunus-universitasterbuka.html. 


\section{HALAMAN INI SENGAJA DIKOSONGKAN}

